\title{
Growth and survival of probiotic bacteria in reconstituted whey
}

\author{
Ida DRGALIĆ*, Ljubica TRATNIK, Rajka BOŽANIĆ \\ Faculty of Food Technology and Biotechnology, University of Zagreb, Pierottijeva 6, Zagreb, Croatia
}

Received 25 June 2004 - Accepted 2 February 2005

Published online 26 April 2005

\begin{abstract}
Considering the potential of whey, based on its nutritional value, the aim of this study was to define the growth and survival of probiotic bacteria in whey and the influence of prebiotic inulin addition on it, for possible production of a nutritive highly valuable whey drink. To get the same experimental conditions, the fermentation was conducted in reconstituted whey with approximately $6 \%$ of total solids. The reconstituted whey was pasteurized and inoculated with three types of commercial probiotic culture: La-5, Bb-12 and Lc-01. Inoculated samples were fermented at $37{ }^{\circ} \mathrm{C}$ for $24 \mathrm{~h}$ and sensory evaluated. Beverages with the highest sensory scores (after 18 hours of fermentation) were cool stored to determine stability. After $28 \mathrm{~d}$ of cool storage the bacterial count was higher than $10^{7} \mathrm{cfu} \cdot \mathrm{mL}^{-1}$ and spoilage was not detected in any sample. Inulin addition had an almost negligible effect on bacterial count during fermentation and cool storage.
\end{abstract}

whey / probiotic / fermentation / growth

Résumé - Croissance et survie de bactéries probiotiques dans du lactosérum reconstitué. Considérant l'intérêt nutritionnel du lactosérum, cette étude a été entreprise pour y définir la croissance et la survie de bactéries probiotiques et l'influence de l'addition d'un prébiotique, l'inuline, dans le but de produire une boisson nutritive. Pour obtenir des conditions expérimentales identiques, la fermentation a été réalisée sur du lactosérum reconstitué à environ $6 \%$ de matière sèche, qui a été ensuite pasteurisé puis inoculé avec 3 types de cultures probiotiques commerciales : La-5, Lb-12 et Lc-01. Les échantillons ont été fermentés à $37^{\circ} \mathrm{C}$ pendant $24 \mathrm{~h}$ et évalués sensoriellement. Les boissons obtenant les meilleurs scores (après $18 \mathrm{~h}$ de fermentation) ont été conservées au froid pour déterminer leur stabilité. Après 28 jours de stockage au froid, les dénombrements bactériens étaient supérieurs à $10^{7} \mathrm{cfu} \cdot \mathrm{mL}^{-1}$ et aucun échantillon ne présentait d'altération. L'addition d'inuline avait un effet pratiquement négligeable sur les dénombrements bactériens au cours de la fermentation et de la conservation au froid.

lactosérum / probiotique / fermentation / croissance

\section{INTRODUCTION}

Whey is a by-product obtained from cheese manufacture, which was often disposed of as waste in the past [11]. Nevertheless, whey is a nutritive highly appreciated product which is insufficiently used in human nutrition. It is a source of the biologically most valuable proteins, and is rich with minerals and vitamins, especially vita$\min B_{2}[8,12,15]$. Because of its health benefits, it has been used to treat some illnesses such as tuberculosis and skin and digestive tract diseases, since the time of

* Corresponding author: idrgalic@pbf.hr 
Ancient Greece [10]. However, the use of whey and whey products in human nutrition is poor. Therefore attempts were made to include whey in different products such as yoghurt, milk-based spreads and bread [4, $6,9,11,12]$. To include whey in all of these products, it was necessary to transform liquid whey into a powder form. That process included new technology and therefore the price of whey powder has increased. As today greater attention is focused on a healthy lifestyle and functional and organic food, the attention should be drawn to the natural whey, in a liquid form. To enrich whey and therefore increase its nutritional value, probiotic microorganisms are one of the best choices for production of a fermented whey beverage.

Probiotics by definition are "live microbial feed supplements which beneficially affect the host animal by improving its intestinal balance" [5]. To improve the bacterial growth of probiotics, prebiotic inulin is added to reconstituted whey. Prebiotics are non-digestible food ingredients that beneficially affect the host by selectively stimulating the growth and/or activity of one or a limited number of bacterial species already resident in the colon [7].

Considering its potential, the aim of this study was to define the growth and survival of probiotic bacteria in whey and the influence of prebiotic addition on it, for possible production of a nutritive highly valuable whey drink.

\section{MATERIALS AND METHODS}

\subsection{Preparation of reconstituted whey}

Since whey differs in chemical composition, depending on the quality of the milk, and the type of cheese made from it, the best way to get the same quality of whey for experiments was to use reconstituted whey. The whey powder used (kindly supplied by "LURA" d.d. Dairy Company, Zagreb, Croatia) was dissolved in water to approx- imately $6.0 \%$ of total solids. To examine the influence of prebiotics on growth and survival of bacteria, inulin was added to the whey samples at an amount of $1 \%$. The whey was then pasteurized at $73{ }^{\circ} \mathrm{C}$ for $15 \mathrm{~s}$ and inoculated with $2 \%$ of probiotic culture at $37^{\circ} \mathrm{C}$.

\subsection{Microbial cultures}

The cultures used were Chr. Hansen's, A/S, Hǿrsholm, Denmark, DVS Lactobacillus acidophilus La-5, Bifidobacterium bifidum $\mathrm{Bb}-12$ and Lactobacillus casei Lc-01. Two $g$ of frozen cultures were added to $98 \mathrm{~mL}$ of reconstituted whey at $37^{\circ} \mathrm{C}$ for activation. After $30 \mathrm{~min}$ of activation, $2 \%$ $(\mathrm{v} / \mathrm{v})$ of the cultures were added to the reconstituted whey. The whey samples with or without inulin addition were then incubated at $37^{\circ} \mathrm{C}$ for $24 \mathrm{~h}$. Chemical and sensory analyses were performed on fermented whey samples after $6,12,18$ and $24 \mathrm{~h}$ of fermentation.

Beverages fermented for $18 \mathrm{~h}$ were cool stored at $8{ }^{\circ} \mathrm{C}$ for $28 \mathrm{~d}$ to determine stability.

\subsection{Sensory evaluation}

Sensory evaluations were determined on day $0,7,14,21$ and 28 by a panel group of 5 sensory analysts. Our intention was to determine if fermentation of whey would result in a drink with acceptable sensory characteristics, so we used a modified scoring system with 1-5 grades for each selected property. The evaluated properties were general appearance, odor and taste. The best grades for general appearance were given to samples with no sediments. Taste was evaluated for acidity and bitterness; however, those properties were not separately evaluated but just as taste. Odor was evaluated for freshness, acid and stable odor; also not separately, but as one characteristic.

\subsection{Chemical and microbiological analyses}

Proteins were determined by the Kjeldahl method, fat by the Gerber method, lactose 
Table I. Chemical composition of reconstituted whey.

\begin{tabular}{lccccccc}
\hline Samples & $\begin{array}{c}\text { Proteins } \\
(\%)\end{array}$ & $\begin{array}{c}\text { Lactose } \\
(\%)\end{array}$ & $\begin{array}{c}\text { Ash } \\
(\%)\end{array}$ & $\begin{array}{c}\text { Dry matter } \\
(\%)\end{array}$ & $\begin{array}{c}\text { Fat } \\
(\%)\end{array}$ & $\mathrm{pH}$ & ${ }^{\circ} \mathrm{SH}$ \\
\hline Average value & 1.03 & 4.14 & 0.46 & 5.77 & $<0.10$ & 6.15 & 3.00 \\
Standard deviation & 0.23 & 0.36 & 0.41 & 0.21 & 0.13 & 0.31 & 0.42 \\
\hline
\end{tabular}

content by the Schoorl-Luff method [14], ash by incineration at $550{ }^{\circ} \mathrm{C}$ and total solids by drying at $105^{\circ} \mathrm{C}$ until constant mass according to the National Standard [1]. Acidity was determined as titratable $\left({ }^{\circ} \mathrm{SH}\right)$ and as $\mathrm{pH}$ value on a Knick $\mathrm{pH}$-meter type 647-1. The viable count of bacteria (cfu $\cdot \mathrm{mL}^{-1}$ ) was determined by the standard method on MRS agar plates (Biolife, Milano, Italy) at $37^{\circ} \mathrm{C}$ for $3 \mathrm{~d}$ in an incubator (Bifidobacterium bifidum in anaerobic conditions, Lactobacillus acidophilus and Lactobacillus casei in microaerophilic conditions), during fermentation (after $0,6,12$, 18 and $24 \mathrm{~h}$ ) and on the $0,7 \mathrm{th}, 14 \mathrm{th}, 21 \mathrm{st}$ and 28th days to determine a bacterial survey during the storage time [1]. Microaerophilic conditions were obtained by a layer of MRS agar over the MRS agar inoculated with bacteria, while anaerobic conditions were obtained in an anaerobic jar with Anaerogen (Oxoid Limited, Hampshire, England).

The experiments were repeated five times. The results were statistically analyzed and are shown as means with standard deviations.

\section{RESULTS AND DISCUSSION}

The reconstituted whey (Tab. I) was incubated at $37{ }^{\circ} \mathrm{C}$ after inoculation with one strain of probiotic bacteria. The fermentation was observed for $24 \mathrm{~h}$. The $\mathrm{pH}$ value at the beginning of the fermentation was around 6.3 and after approximately $5 \mathrm{~h}$ started to drop obviously, in all samples, regardless of inulin or probiotic strain addition. The results of a decrease in $\mathrm{pH}$ with or without inulin were the same during fermentation and storage in all samples (data are thus not shown separately). Therefore inulin addition had a negligible influence on the dynamics of $\mathrm{pH}$ decrease. The quickest $\mathrm{pH}$ decrease was observed in samples with the La-5 probiotic strain, as suggested in the literature [13], while Lc-01 had the slowest decrease. Also, samples inoculated with $\mathrm{La}-5$ had the lowest $\mathrm{pH}$ values after $24 \mathrm{~h}$ of fermentation (Fig. 1). After $24 \mathrm{~h}$ of fermentation $\mathrm{pH}$ values of all samples were lower than 4.5. Similar results for La-5 were obtained in cow's and goat's milk fermentation [3], while Bb-12 shows different acid production in whey (Fig. 1) than in milk [2]. Considering acid production with $\mathrm{Bb}-12$ culture, it takes approximately $28 \mathrm{~h}$ of goat's milk fermentation, more than $28 \mathrm{~h}$ for cow's milk fermentation [2] and around $20 \mathrm{~h}$ of whey fermentation to achieve a $\mathrm{pH}$ around 4.5. $\mathrm{pH}$ values of both fermented milk types [2] and fermented whey using $\mathrm{Bb}-12$, during cold storage, show almost no difference and are constantly around the same value.

Titratable acidity $\left({ }^{\circ} \mathrm{SH}\right)$ started to increase in all samples in the first hour of fermentation, and the main increase was observed between the 12th and 18th hours (Fig. 2) which is in correlation with the $\mathrm{pH}$ decrease of samples. The highest titratable acidity after $24 \mathrm{~h}$ of fermentation was observed in samples inoculated with strain La-5 ( $\left.{ }^{\circ} \mathrm{SH}=16.8\right)$, which was expected, since the same sample had the lowest $\mathrm{pH}$ value. Inulin addition had a negligible effect on the dynamics of titratable acidity changes during fermentation. Therefore, the results for samples with and without inulin addition are not shown separately, but regardless of inulin addition. Viable cells were determined as $\mathrm{cfu} \cdot \mathrm{mL}^{-1}$. During fermentation it was observed that La-5 


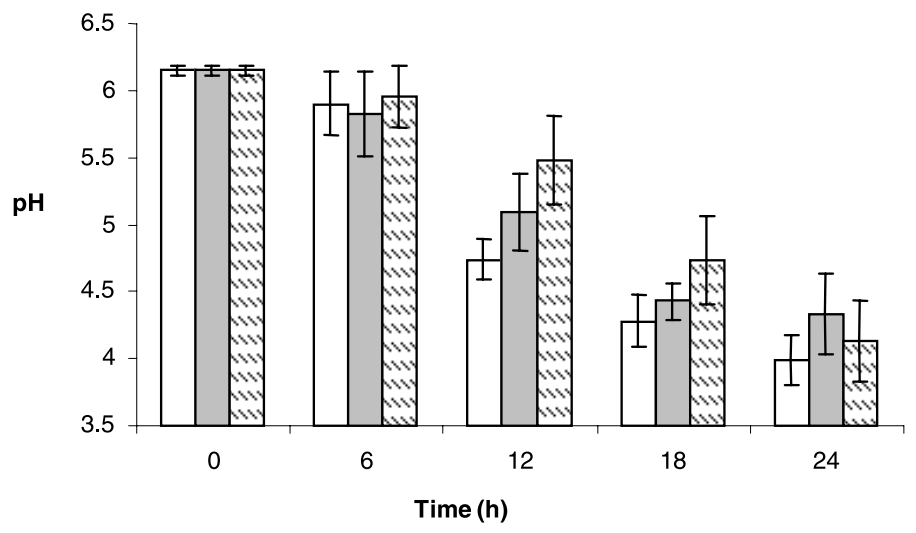

Figure 1. $\mathrm{pH}$ values of whey samples during $24 \mathrm{~h}$ of fermentation regardless of inulin addition $\mathrm{La}, \square \mathrm{Bb}, \mathrm{\textrm {Lc }})$.

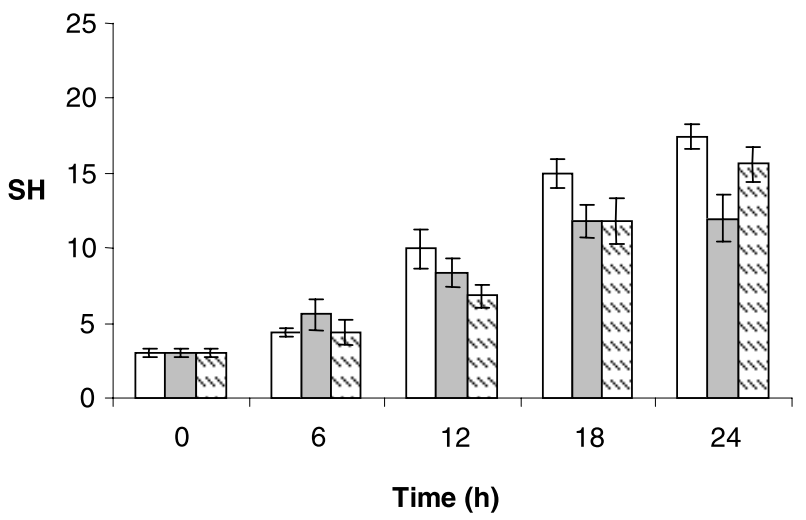

Figure 2. Titratable acidity $\left({ }^{\circ} \mathrm{SH}\right)$ of whey samples during fermentation, regardless of inulin addition $\mathrm{La}, \square \mathrm{Bb}, \mathrm{\textrm {Lc }})$.

started to grow slowly immediately after inoculation just like samples inoculated with Bb-12 and inulin, while the viable cells of Lc-01 decreased. Lc-01 and La-5 showed similar dynamics of growth with a significant increase in number between the 6 th and 12th hours of fermentation (Fig. 3a). Samples inoculated with $\mathrm{Bb}-12$ grew more or less in the same dynamics, with no rapid changes in viable cell count (Figs. 3a and $3 b)$. The increase in viable cells of Bb-12 (around 0.6 units of the logarithmic scale) after $24 \mathrm{~h}$ of fermentation, was much smaller than the increase in viable La-5 and Lc-01. Between 12 and $18 \mathrm{~h}$ of fermentation the number of cells of La-5 and Lc-01 slightly decreased, and after the 18th started to increase again at a slower rate. This property was not observed in the case of samples inoculated with Bb-12 (Figs. 3a and 3b). Inulin addition had no significant influence on bacteria growth in all inoculated samples of whey (Fig. 3b). The highest viable cell count for all samples was between 8 and $8.5 \log \mathrm{cfu} \cdot \mathrm{mL}^{-1}$ and it was obtained after $24 \mathrm{~h}$ of fermentation. The same results were 


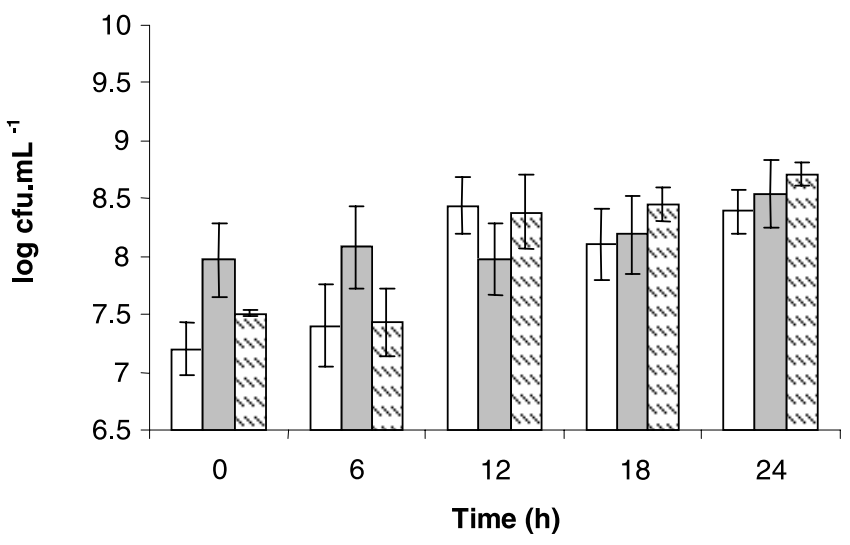

Figure 3a. Viable cell count during fermentation of whey samples without inulin addition $\left(\square \mathrm{La}, \square \mathrm{Bb}, \mathrm{SLc}^{\mathrm{L}}\right.$.

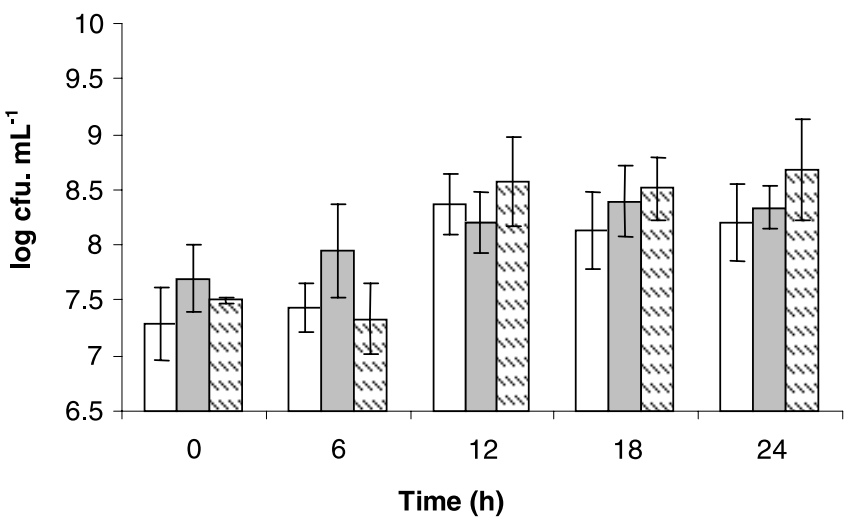

Figure 3b. Viable cell count during fermentation of whey samples with inulin addition $\left(\square \mathrm{La}, \square \mathrm{Bb}, \mathbf{Q}_{\mathrm{Lc}}\right)$

obtained in the research of Božanić et al. with La-5 and Bb-12 in cow's and goat's milk [2, 3]. Inulin addition had a positive effect on Lc-01 during the log phase of growth causing a greater, not significant increase in bacterial count (Fig. 3b). Regardless of inulin addition, Lc-01 showed the best growth after $24 \mathrm{~h}$ of fermentation.

The samples were sensory evaluated by a panel group of 5 members after $6,12,18$ and $24 \mathrm{~h}$ of fermentation (Tab. II). The best sensory scores were given to samples which were fermented for $18 \mathrm{~h}$. The sensory scores of products fermented for less than $18 \mathrm{~h}$ were too mild and without a sour taste, while samples fermented for $24 \mathrm{~h}$ were too sour (Tab. II).

It was noticed that all samples had an excellent appearance, samples inoculated with La-5 and Lc-01 had a pleasant taste after $18 \mathrm{~h}$ of fermentation, but samples inoculated with Bb-12 had a very poor taste and odor during complete fermentation. Since the best grades were given to samples that were fermented for $18 \mathrm{~h}$, these were chosen for the estimation of stability in 
Table II. Average sensory evaluations (grades 1-5) of whey samples during fermentation regardless of inulin addition.

\begin{tabular}{llllll}
\hline Sample & & \multicolumn{3}{l}{ Hours of fermentation } \\
& Sensory properties & 6 & 12 & 18 & 24 \\
\hline La-5 & Taste & 2.0 & 3.0 & 5.0 & 4.0 \\
& Standard deviation & 0.23 & 0.33 & 0.27 & 0.41 \\
& Odor & 2.5 & 2.5 & 3.5 & 4.0 \\
& Standard deviation & 0.22 & 0.21 & 0.31 & 0.30 \\
& General appearance & 5.0 & 5.0 & 5.0 & 5.0 \\
& Standard deviation & 0.00 & 0.00 & 0.01 & 0.05 \\
\hline Bb-12 & Taste & 1.5 & 1.5 & 1.5 & 1.5 \\
& Standard deviation & 0.03 & 0.10 & 0.07 & 0.10 \\
& Odor & 1.5 & 1.5 & 1.5 & 1.5 \\
& Standard deviation & 0.21 & 0.23 & 0.31 & 0.13 \\
& General appearance & 5.0 & 5.0 & 5.0 & 5.0 \\
& Standard deviation & 0.00 & 0.00 & 0.01 & 0.00 \\
\hline Lc-01 & Taste & 2.0 & 3.0 & 5.0 & 3.0 \\
& Standard deviation & 0.32 & 0.21 & 0.40 & 0.31 \\
& Odor & 2.0 & 2.0 & 4.0 & 2.0 \\
& Standard deviation & 0.50 & 0.21 & 0.31 & 0.40 \\
& General appearance & 5.0 & 5.0 & 5.0 & 5.0 \\
& Standard deviation & 0.00 & 0.01 & 0.00 & 0.00 \\
\hline
\end{tabular}

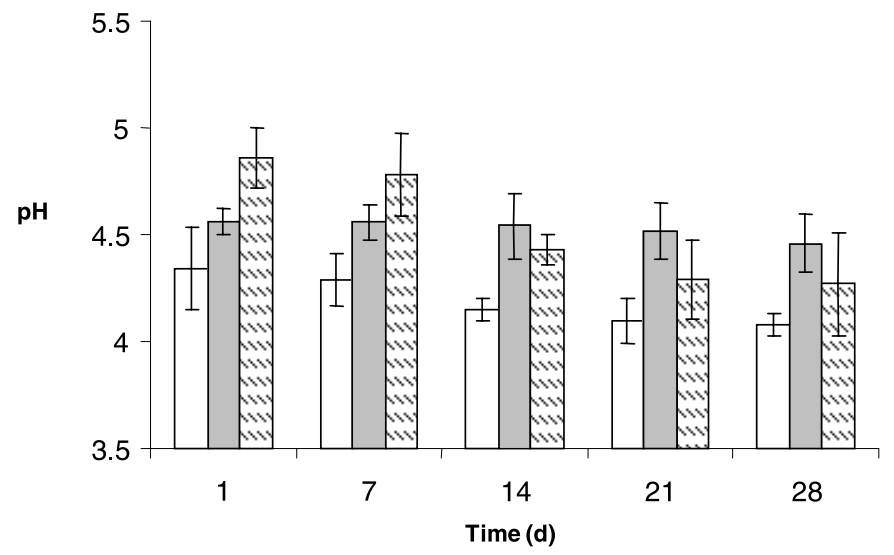

Figure 4. $\mathrm{pH}$ values of fermented whey samples during $28 \mathrm{~d}$ of cool storage regardless of inulin addition $(\square \mathrm{La}, \square \mathrm{Bb}, \mathrm{MLc})$. refrigeration conditions. It was noticed that the $\mathrm{pH}$ decrease was obvious in samples inoculated with Lc-01 (around $0.5 \mathrm{pH}$ units) and La-5 (around $0.3 \mathrm{pH}$ units), while samples inoculated with Bb-12 had almost no $\mathrm{pH}$ decrease during $28 \mathrm{~d}$ of storage regardless of inulin addition (Fig. 4).
Titratable acidity $\left({ }^{\circ} \mathrm{SH}\right)$ increased in all fermented whey samples regardless of inulin addition (Fig. 5). The most interesting aspect of our research was to determine bacterial survival in reconstituted fermented whey and the influence of prebiotic addition on bacterial count. Whey samples 

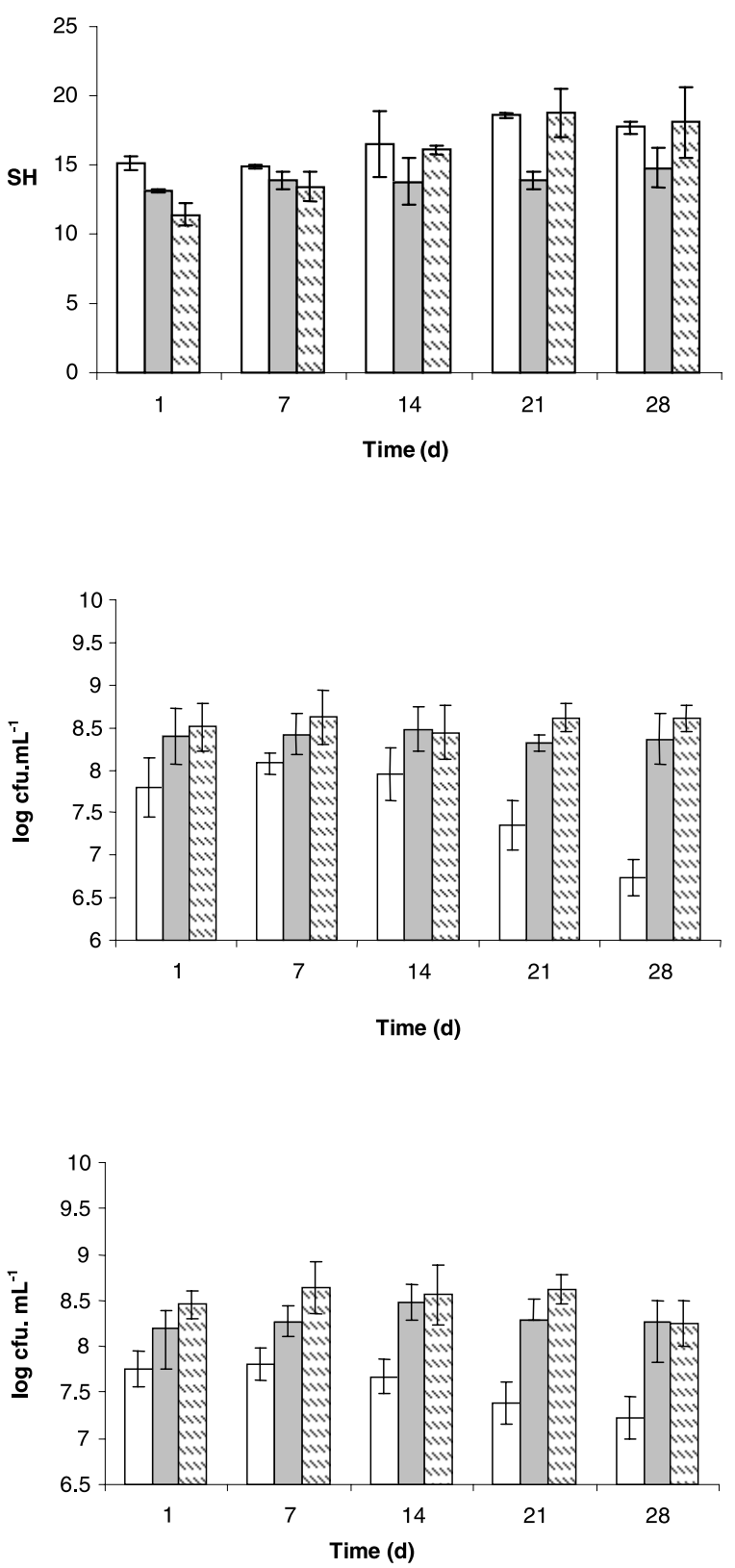

Figure 5. Titratable acidity of fermented whey samples during cool storage regardless of inulin addition $(\square \mathrm{La}, \square \mathrm{Bb}, \mathrm{\textrm {Lc }})$.
Figure 6a. Viable cell counts of fermented whey samples with inulin addition during storage ( $\square \mathrm{La}, \square \mathrm{Bb}, \mathrm{Lc}_{\mathrm{L}}$ )
Figure 6b. Viable cell counts of fermented whey samples without inulin addition during storage ( $\left.\square \mathrm{La}, \square \mathrm{Bb}, \mathbf{Q}_{\mathrm{Lc}}\right)$. fermented with La- 5 without inulin showed a decrease in bacterial count from the 1st day forward (Fig. 6a), while samples with inulin showed excellent stability during $14 \mathrm{~d}$ of storage, but after the 14th day the bacterial count started to decrease (Fig. 6b). 


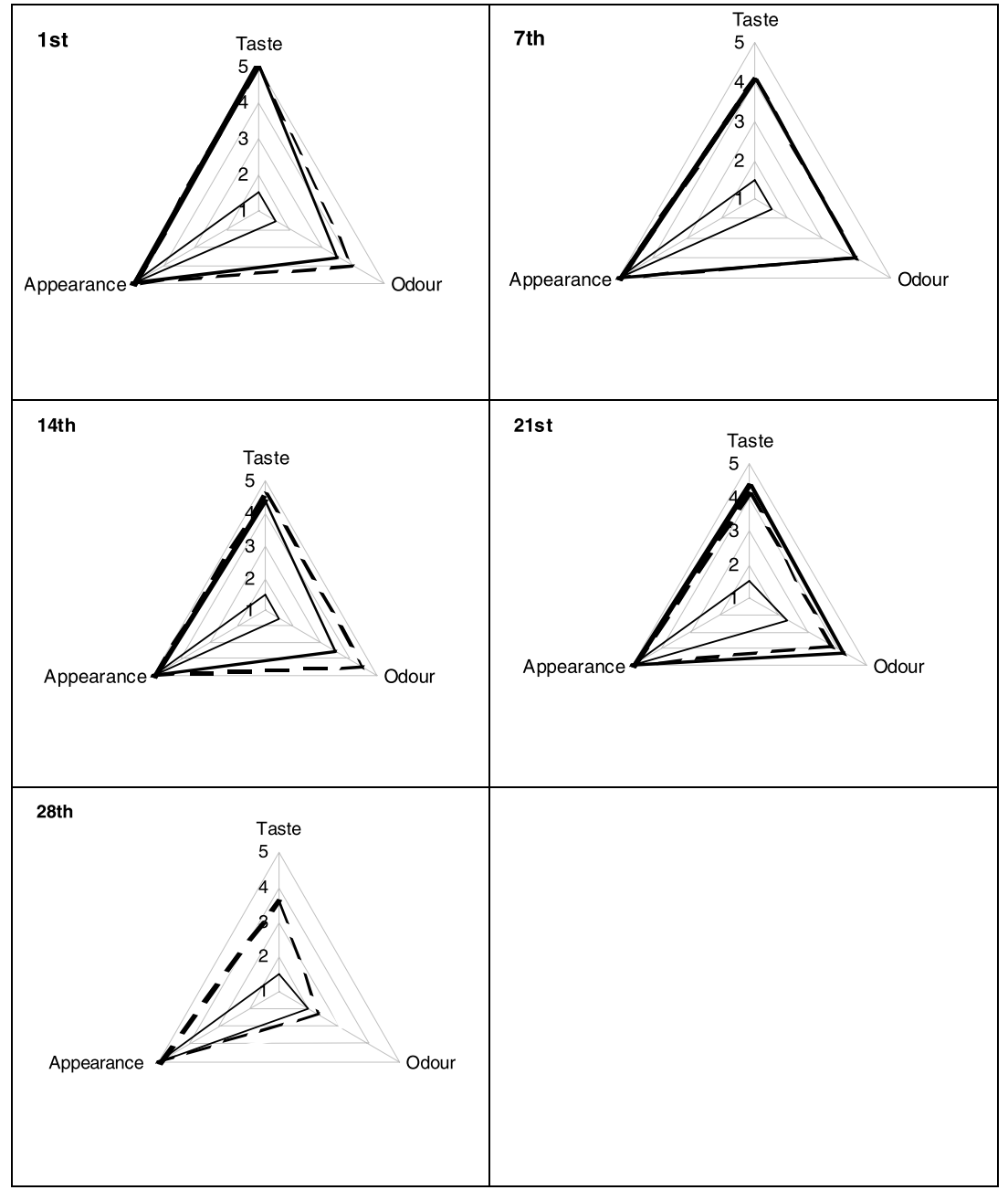

Figure 7. Sensory evaluation of whey samples fermented for $18 \mathrm{~h}$ with La-5, Bb-12 or Lc-01 on the 1st, 7th, 14th, 21st and 28th d of storage (- La, - Bb, - - Lc).

Bb-12 and Lc-01 were stable throughout the time of storage without a significant change in bacterial count.

Sensory evaluation during cool storage was performed for samples that were fermented for 18 hours. The aim was to determine the acceptability of products and stability. The evaluations were performed on the 0 , 7 th, 14 th, 21 st and 28 th days of storage. The results show that samples inoculated with La-5 or Lc-01 had satisfactory sensory scores, while samples inoculated with Bb-12 were unacceptable during cool storage (Fig. 7). It can be noticed that samples inoculated with La- 5 had the best sensory scores after $21 \mathrm{~d}$ of storage, while samples inoculated with Lc-01 were the best after $14 \mathrm{~d}$ of storage. Samples inoculated with Bb-12 
had unsatisfactory results for taste (because of bitterness and sourness) and for odor (because of stable flavor), but after $21 \mathrm{~d}$ of storage these properties slightly improved. All samples had excellent scores for appearance regardless of storage time or inoculated bacteria. Inulin addition had no effect on any sensory property of any samples regardless of storage time.

\section{CONCLUSIONS}

The usage of whey in human nutrition can be enhanced by production of fermented probiotic whey beverages. The results of the experiments in this paper show that the chosen probiotics do not significantly increase their number during fermentation, but survive in refrigerated conditions for at least $28 \mathrm{~d}$ in a number greater than $10^{7} \mathrm{cfu} \cdot \mathrm{mL}^{-1}$ which is essential if a product should have probiotic properties. The best sensory score had beverages fermented for $18 \mathrm{~h}$ and therefore, those were chosen for determination of stability. It is important to emphasize that all the beverages produced possessed excellent stability during $28 \mathrm{~d}$ of storage, and spoilage was not noticed in any sample. The sensory scores of the beverages are high, except samples fermented with Bb-12, but in further research acceptability should be investigated and improved.

\section{REFERENCES}

[1] Association of Official Analytical Chemists (16th edn.), Official Methods of Analysis, vol. 2, AOAC, Arlington, VA, USA, Secs. 33.2.11, 1995.

[2] Božanić R., Tratnik L.J., Quality of cow's and goat's fermented bifido milk during storage, Food Technol. Biotechnol. 39 (2001) 109-114.

[3] Božanić R., Rogelj I., Tratnik L.J., Fermented acidophilus goat's milk supplemented with inulin: comparison with cow's milk, Milchwissenschaft 56 (2001) 618-622.

[4] Erdogdu-Arnoczky N., Czughajkowska Z., Pomeranz Y., Functionality of whey and casein in fermentation and in breadbacking by fixed and optimized procedures, Cereal Chem. 73 (1996) 309-316.

[5] Fuller R., Probiotics in man and animals J. Appl. Bacteriol. 66 (1989) 365-378.

[6] Gelinas P., Lachance O., Development of fermented dairy ingredients as flavour enchancers for bread, Amer. Assoc. Cereal Chem. 72 (1995) 17-21.

[7] Gibson G.R., Roberfroid M.B., Dietary modulation of the human colonic microbiota: introducing the concept of prebiotics, J. Nutr. 125(1995)1401-1412.

[8] Ha E., Zemel M.B., Functional properties of whey, whey components, and essential amino acids: mechanism underlying health benefits for active people, J. Nutr. Biochem. 14 (2003) 251-258.

[9] McIntosh G.H., Royle P.J., Le Leu R.K., Regester G.O., Johnson M.A., Grinsted R.L., Kenward R.S., Smithers G.W., Whey proteins as functional food ingredients?, Int. Dairy J. 8 (1998) 425-434.

[10] Popović-Vranješ A., Vujičić I.F., Tehnologija surutke (Technology of whey), Poljoprivredni fakultet Novi Sad (Agricultural Faculty Novi Sad), Novi Sad, 1997.

[11] Rodriguez-Serrano G., Perez-Hernandez G. Gallardo F., Gomez-Ruiz L., Garcia-Garibay M., Performance of yogurt cultures during fermentation of whey concentrated by ultrafiltration for the elaboration of a fermented beverage, Milchwissenschaft 57 (2002) 540 543.

[12] Shah N.P., Effects of milk-derived bioactives: an overview, Brit. J. Nutr. 84 (2000) 252-256.

[13] Skudra L., Blija A., Sturmoviča E., Dukalska L., Aboltinš A., Karklina D., Studies on whey fermentation using lactic acid bacteria $L$. acidophilus and L. bulgaricus, Acta Biotechnol. 18 (1998) 277-288.

[14] Trajković J., Baras J., Mirić M., Šiler S., Analize životnih namirnica (Analysis of Food), Tehnološko - metalurški fakultet (Faculty of Technology and Metal), Beograd, 1983.

[15] Tratnik L.J., Mlijeko - tehnologija, biokemija i mikrobiologija (Milk - technology, biochemistry and microbiology), Hrvatska Mljekarska Udruga (Croatian Dairy Union), Zagreb, 1998. 